\title{
Ethnicity, Migration, and Entrepreneurship in Indonesia
}

\author{
${ }^{* 1}$ Cahyono, Erwin, ${ }^{2}$ Syafitri, Wildan \& ${ }^{3}$ Susilo \\ ${ }^{*}$ Pemerintahan Kabupaten Tulungagung \\ 2 Universitas Brawijaya, Malang, Indonesia \\ ${ }^{3}$ Universitas Brawijaya, Malang, Indonesia
}

Note: * Indicates corresponding author

\begin{tabular}{|c|c|}
\hline ARTICLE DETAILS & ABSTRACT \\
\hline $\begin{array}{l}\text { Article History } \\
\text { Published Online: publisher use only }\end{array}$ & \multirow{4}{*}{$\begin{array}{l}\text { Extant studies demonstrate the vital roles of ethnicity group and } \\
\text { culture influencing individual intention and decision to become an } \\
\text { entrepreneur. Meanwhile, in the entrepreneurial decision, each } \\
\text { ethnic group has different preferences regarding where to run it, at } \\
\text { the origin or overseas. This study examines the roles of group } \\
\text { ethnicity and culture in affecting the likelihood of an individual's } \\
\text { choosing entrepreneurship as their occupation using the combined } \\
\text { data of the Indonesian Family Life Survey (IFLS) and the } \\
\text { Population Census Report. Our findings substantiate that group } \\
\text { ethnicity and culture significantly influence the likelihood of } \\
\text { entrepreneurial decisions. Furthermore, using Javanese as a } \\
\text { reference, we found the Balinese, Batak, Chinese, South } \\
\text { Sumatran, and Minangkabau tend towards entrepreneurship. The } \\
\text { difference is that the Balinese, Batak, Chinese, and South } \\
\text { Sumatran tend to run their business around where they live, while } \\
\text { the Minangkabau are overseas. }\end{array}$} \\
\hline $\begin{array}{l}\text { Keywords } \\
\text { Ethnicity; Migration; } \\
\text { entrepreneurship; IFLS. }\end{array}$ & \\
\hline "Corresponding Author & \\
\hline Email:erwin.cahyono.9@gmail.com & \\
\hline
\end{tabular}

\section{INTRODUCTION}

Economists agree the optimal number of entrepreneurs is considered a solid foundation in a country's economic building system (Ciputra, 2009). For example, as the world's most entrepreneurial, dynamic, and flexible economy, the dynamism and flexibility of the United States have allowed its economy to adapt to changing circumstances and recover from the recession in a strong way (Decker, Haltiwanger, Jarmin, \& Miranda, 2014).

However, a different fact is happened through most developing countries, including Indonesia, there are not enough number entrepreneurs. In Indonesia, the number of entrepreneurs in 2020 according to the State Minister for Cooperatives Small and Medium Enterprises is only $3.5 \%$ (2017), or only around 9 million people from 260 million of the total population. Meanwhile, in most developed countries, the ratio of entrepreneurs is $14 \%$ of the total population.
It needs to be a concern because the Indonesian culture thinks that formal work is still the primary choice as a future goal. An entrepreneur is considered to be full of risk because he put himself against the possibility of shocks from his company, while the manager (employee) is the more relatively safe position in working with the salary he receives (Hadiyati, 2011). That is why entrepreneurship is always seen as the last alternative after failure in trying to get a formal occupation for most job seekers in Indonesia.

Entrepreneurship has been articulated as a reflection of the robustness of a new field, which sprouts with new ideas and thoughts (Gartner, 1990). Meanwhile, the oldest opinion that has used a formal theory of the concept of entrepreneurship appeared in the work of Richard Cantillon around the 1730s (Wayne, 1983). According to Cantillon, an entrepreneur is defined as an independent worker, who carries out his activities according to market needs. These entrepreneurs are always able to 
see opportunities in the field, develop them, and then open new businesses.

In the neoclassical era, entrepreneurship theory was marked by the emergence of the term "Creative Destruction" in the 1950s, popularized by Joseph Schumpeter. According to Schumpeter, this "Creative Destruction" describes a process of industrial change that continually revolutionizes the economic structure endlessly from within, and destroys the old, then creates innovations. He emphasized that entrepreneurs can do new things or do already things, but done in new ways (Schumpeter, 1947). After that, the entrepreneurial approach developed into a variety of multi-disciplines. We can see entrepreneurial activity from the opportunity factor, technology, and the human factor itself. Till the modern theories show a linkage of environmental factors (culture/ethnicity) to entrepreneurship.

Entrepreneurial decisions, in general, are often considered as choices that are taken and made personally, even though the process of initiating an entrepreneurial process actually not only arises from the foundation of one's intuition, there are group and cultural influences (Morrison, 2000). The evidence suggests that between culture and entrepreneurship interaction is seen stronger in some ethnic group's case than for other factors (A. Basu \& Altinay, 2002). It means that apart from hereditary biological factors and visible physical characteristics, each ethnicity has different personality traits, as well as different cultural values and norms (Rossiter \& Chan, 1998). According to Rossiter and Chan, these cultural values and norms have a large genetic component. Anthropologists pay attention to how a child is taught in a specific culture, for example, the way he is named, the way he is carried and then taught to walk, talk, how he is placed in the kinship system, how he acquires property, how he is initiated, married, and until he is buried (Mead, 1963). So the chances of being passed on to the next generation also have a great opportunity. Even on basic economic problems, this cultural hypothesis can be rigorously tested and might be considered significant, such as concerning individual savings rates (Guiso, Sapienza, \& Zingales, 2006).

Indarti (2020) classifies the approaches used for ethnicity and entrepreneurship into three categories: (1) The socio-cultural field; (2) The socio-economic field; and (3) The combination of socio-cultural and economics fields. The socio-cultural theory was based on Bandura (1978), which states that a person's behavior patterns occur from the results of observing and imitating the behavior of others. It illustrates the intention of an ethnic group that opens a business based on imitating the other members. This theory helps explain environmental factors such as "role models" that motivate ethnic group members to become entrepreneurs as a career choice.

In the socio-economic field, migration is noticed as affecting entrepreneurship. Due to differences in regional characteristics, it is possible to obtain more economic benefits in other regions. Dorigo \& Tobler (1983) stated that to achieve better economic conditions and opportunities, the decision to move to another area could be an option. Furthermore, the theory of bootstrap capitalism (D. Basu \& Werbner, 2001) also explains how ethnic minorities build their businesses from limited capital and then trying to determine their economic means by immersing themselves in this new environment.

The combination of socio-cultural and economic fields viewpoints is that it compliments each other in explaining how ethnic workers can survive and view their minority status towards the ethnicities they meet in overseas areas. In this perspective, the minority's economic status is in the middle position. So, to being survived, they must be able to mingle with the community, then build their business in the economic system in the area (Bonacich, 1973).

Related to the ethnicity's influence on Indonesian migration culture, Auwalin (2019) argues that ethnic identity has a role in each migration decision. It turns out that each ethnic group has a different tendency towards migrating decisions. Some studies conclude, those who decide to migrate hope for higher economic benefits by moving, more than they obtained when choosing to stay in their homeland (Levie, 2007; Williams, Baláz, Wallace, \& Williams, 2004).

Research based on Indonesian Family Life Survey (IFLS) 2015 (Strauss, Witoelar, \& Sikoki, 2016). The object is the Indonesian population of various ethnic groups, that the dataset sample is $83 \%$ of Indonesia's population representation. The sampling consisted of more than 30,000 individuals who were surveyed in 13 provinces across Indonesia. As a consideration in acquiring accurate and reliable research objects, research also involves Population Census Result data by the Central Statistics Agency/Badan Pusat Statistik (BPS). The combination of data from IFLS and BPS is expected will produce a strong conclusion and fulfill the research principles.

The number of entrepreneurs in Indonesia 


\section{Ethnicity, Migration, and Entrepreneurship in Indonesia}

is a representation of all different ethnicities. Due to the dominating number, we use Javanese as a reference by other tribes. We hypothesize that there are ethnic groups that have a dominant role in the data compared to Javanese. Hence, the main object of this research is analyzing ethnic groups that have a higher proportion in shaping the entrepreneur's composition in Indonesia. And then analyze how individual and household characteristics in making entrepreneurial decisions. It can be a valuable basis for strategic planning to increase the number of entrepreneurs in Indonesia.

We use 12 ethnic groups in Indonesia with the largest population level, which is more than 2 million people based on the 2010 Population Census enumeration, as observation objects. The 12 ethnic groups are Javanese, Sundanese, Balinese, Batak, Bugis, Chinese, Madurese, Sasak, Minangkabau, Banjar, Betawi, and South Sumatran.

For the statistical method, we use logistic regression. This mathematical modeling approach can be applied to describe a relationship of several independent variables to a dichotomy of the dependent variable (Latan, 2014, p. 215). In this logistic regression, a Maximum Likelihood estimation method is used when this method maximizes the probability of the observed value from the data set (Hosmer \& Lemeshow, 2000, p. 8). The conditions, a large number of samples are required to get a safe estimate. We have from the IFLS, a large number of survey data were provided with more than 1000 samples for each variable. Therefore, this assumption can be fulfilled properly.

The model used is as follows:

$\log \frac{p}{1-p}=\beta_{0}+\beta_{i}$ ethnicity $_{i}+\beta_{i}$ migration $+\beta_{i}(\text { ethnicity } * \text { migration })_{i}+$ $\beta_{i}$ individual_characteristics $_{i}+\beta_{i}$ household_characteristics $_{i}$

Where, $p$ is the possibility of Entrepreneurship (dependent variable), $\beta_{0}$ is the variable regression coefficient, $\beta_{i}$ ethnicity $y_{i}$ is the main independent variable, namely the largest ethnicity in Indonesia, $\beta_{2}$ migration is the migration variable, $\beta_{i}(\text { ethnicity } * \text { migration })_{i}$ represents ethnicity which has the influence of migration as an interaction variable, $\beta_{i}$ individual_characteristics $_{i}$ are independent variables of individual characteristics there are age, gender, marital status, muslim/non muslim, obedience, education, read ability, and health. $\quad \beta_{i}$ household_characteristics ${ }_{i}$ are independent variables of household characteristics, there are consumption expenditure, parental education, parents' job,
Dominant income in the family, rural/urban, family size, and no job status. $i$ is the $1,2,3$ predictor variable, $\ldots \mathrm{n}$

\section{FINDINGS}

\subsection{Ethnic Distribution}

With a density level being ranked 4th in global after China, India, and the United States, Indonesia has a very great ethnic diversity. Within these ethnic groups, Indonesians are loyal to kinship, regional, and local groupings, and often their behavior is influenced by group norms formalized into customary law (Hugo, 2015). Thus each ethnic group in Indonesia has different unique traditions and cultures.

The 2010 Population Census report said there are at least 1,340 different ethnic groups in Indonesia, with more than 30 ethnic groups have more than 1 million population (Badan Pusat Statistik, 2012). Figure 1 is the percentage of the ethnic population based on the largest order in Indonesia. The Javanese are the most numerous ethnic groups, as much as $40 \%$ spread throughout Indonesia.

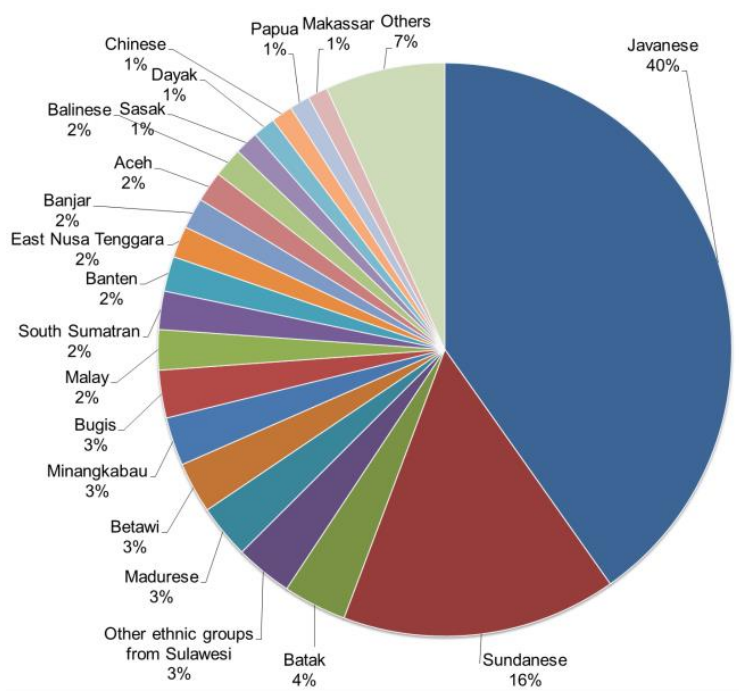

Figure 1. Composition of Indonesian Population According to Ethnic Groups

Source: BPS, 2012

BPS has classified Indonesia's administrative areas into seven regional groups based on the largest islands. Specifically are Sumatra, Java and Bali, Nusa Tenggara, Kalimantan, Sulawesi, Maluku, and Papua. Table 1 shows the results of the 2010 Population Census and the 2000 Population Census. The table shows that Indonesian ethnicities spread out to the archipelago peripheral not only live in their origin. 
Furthermore, it also explains the ethnic distribution direction in the seven Administrative Regions shows a constant pattern. Although the numbers fluctuate, the proportion of tribes that migrate and spread out is relatively the same from year to year. The trend towards migration destinations does not correlate with the distance range of the origin.
An example is the Banjar, which tends more to migrate to Java or Sumatra than to Sulawesi, which is nearer. Or the Bugis that is more likely to migrate to Sumatra than to Nusa Tenggara. It implies the fact that ethnic tendencies to migrate to certain areas is affected by the direction of their predecessors' migration habits.

Table 1. Ethnic Distribution in 7 Administrative Regions in Indonesia SP 2010 and SP 2000

\begin{tabular}{|c|c|c|c|c|c|c|c|c|c|c|c|c|}
\hline \multirow{2}{*}{ Administrative Region } & \multicolumn{2}{|c|}{ Javanese } & \multicolumn{2}{|c|}{ Sundanese } & \multicolumn{2}{|c|}{ Minang } & \multicolumn{2}{|l|}{ Sasak } & \multicolumn{2}{|c|}{ Balinese } & \multicolumn{2}{|l|}{ Batak } \\
\hline & 2010 & 2000 & 2010 & 2000 & 2010 & 2000 & 2010 & 2000 & 2010 & 2000 & 2010 & 2000 \\
\hline Sumatra & 15.239 .275 & 12.425 .981 & 1.231 .888 & 997.961 & 5.799 .001 & 4.934 .770 & 9.225 & N/A & 153.107 & N/A & 7.302 .330 & N/A \\
\hline Java and Bali & 76.125 .459 & 68.607 .006 & 35.220 .057 & 29.786 .365 & 631.462 & 515.313 & 34.546 & N/A & 3.407 .457 & N/A & 1.030 .385 & N/A \\
\hline Nusa Tenggara & 133.427 & 87.135 & 6.453 & 4.573 & 4.225 & 2.363 & 3.035 .698 & N/A & 125.974 & N/A & 4.804 & N/A \\
\hline Borneo & 2.499 .950 & 1.778 .714 & 158.276 & 127.003 & 17.420 & 13.719 & 40.412 & N/A & 29.907 & N/A & 88.363 & N/A \\
\hline Sulawesi & 772.428 & 567.591 & 57.411 & 41.993 & 5.150 & 7.061 & 46.365 & N/A & 225.259 & N/A & 15.287 & N/A \\
\hline Maluku & 122.064 & 74.763 & 7.049 & 3.456 & 2.730 & 611 & 508 & N/A & 1.861 & N/A & 2.371 & N/A \\
\hline \multirow[t]{3}{*}{ Papua } & 344.419 & 211.663 & 20.536 & 17.053 & 2.725 & 1.308 & 3.035 & N/A & 2.851 & N/A & 23.429 & N/A \\
\hline & \multicolumn{2}{|c|}{ Bugis } & \multicolumn{2}{|c|}{ Banjar } & \multicolumn{2}{|c|}{ Betawi } & \multicolumn{2}{|c|}{ South Sumatran } & \multicolumn{2}{|c|}{ Madurese } & \multicolumn{2}{|l|}{ Chinese } \\
\hline & 2010 & 2000 & 2010 & 2000 & 2010 & 2000 & 2010 & 2000 & 2010 & 2000 & 2010 & 2000 \\
\hline Sumatra & 348.272 & 244.430 & 472.365 & 216.581 & 38.445 & 29.233 & 1.379 .351 & N/A & 44.079 & 37.980 & 642.133 & N/A \\
\hline Java and Bali & 155.633 & 98.189 & 38.142 & 37.333 & 6.753 .205 & 4.998 .330 & 31.257 & N/A & 6.700 .826 & 6.371 .078 & 1.481 .767 & N/A \\
\hline Nusa Tenggara & 42.446 & 33.610 & 1.283 & 993 & 2.042 & 940 & 225 & N/A & 3.692 & 2.734 & 15.407 & N/A \\
\hline Borneo & 951.363 & 643.697 & 3.605 .770 & 3.071 .842 & 8.963 & 5.754 & 3.381 & N/A & 416.362 & 332.355 & 409.338 & N/A \\
\hline Sulawesi & 4.687 .190 & 3.911 .782 & 8.773 & 7.456 & 3.960 & 4.997 & 451 & N/A & 6.595 & 9.436 & 69.667 & N/A \\
\hline Maluku & 46.053 & 18.974 & 315 & 253 & 3.679 & 343 & 145 & N/A & 1.938 & 1.383 & 6.860 & N/A \\
\hline Papua & 128.743 & 59.604 & 492 & 365 & 1.160 & 2.091 & 737 & N/A & 4.842 & 2.595 & 5.830 & N/A \\
\hline
\end{tabular}

Source: BPS, compiled

The interesting is when viewed by the number of ethnic diversity based on administrative regions/islands, Java Island as the original of the Javanese is the least diverse compared to other administrative, as in Figure 2. Based on its diversity, Papua Island is the most varied, which has 465 ethnic groups. Nevertheless, the population of each tribe is less than one million people. In this report, ethnic groups with populations of one million or more are considered separate groups (Na'im \& Syaputra, 2011).

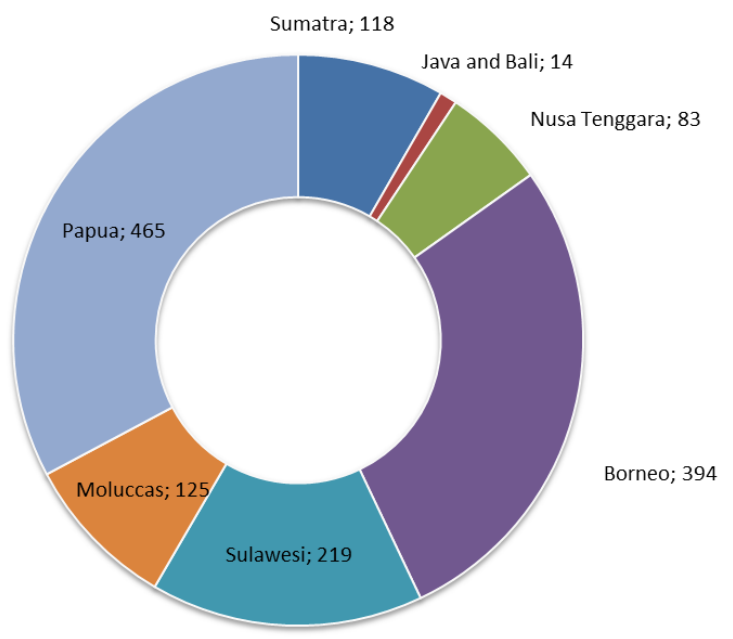

Figure 2. Number of Tribes According to 7 Administrative Regions

Source: BPS, 2012

The observations also show the ratio of outgoing temporary migrants throughout Indonesia from 1980 to 2015 is relatively fixed in rank, as recorded in BPS data (Figure 3). We have calculated $58 \%$ of the total outgoing migrants from all outgoing migration in Indonesia are from Java-Bali's ethnic group, $23 \%$ of out-migrants in Indonesia are from Sumatra's ethnic group, and $7 \%$ are from Borneo's (Kalimantan) ethnic group. Meanwhile, Sulawesi at $6.5 \%$, Papua at $1.5 \%$, and Maluku at $0.9 \%$.

The migration decision to the destination place must be not only based on just speculation, considering that migration requires funds to support such as for transportation and accommodation. Till mastery of references about the characteristics of the destination from their predecessors is very necessary for successors. 


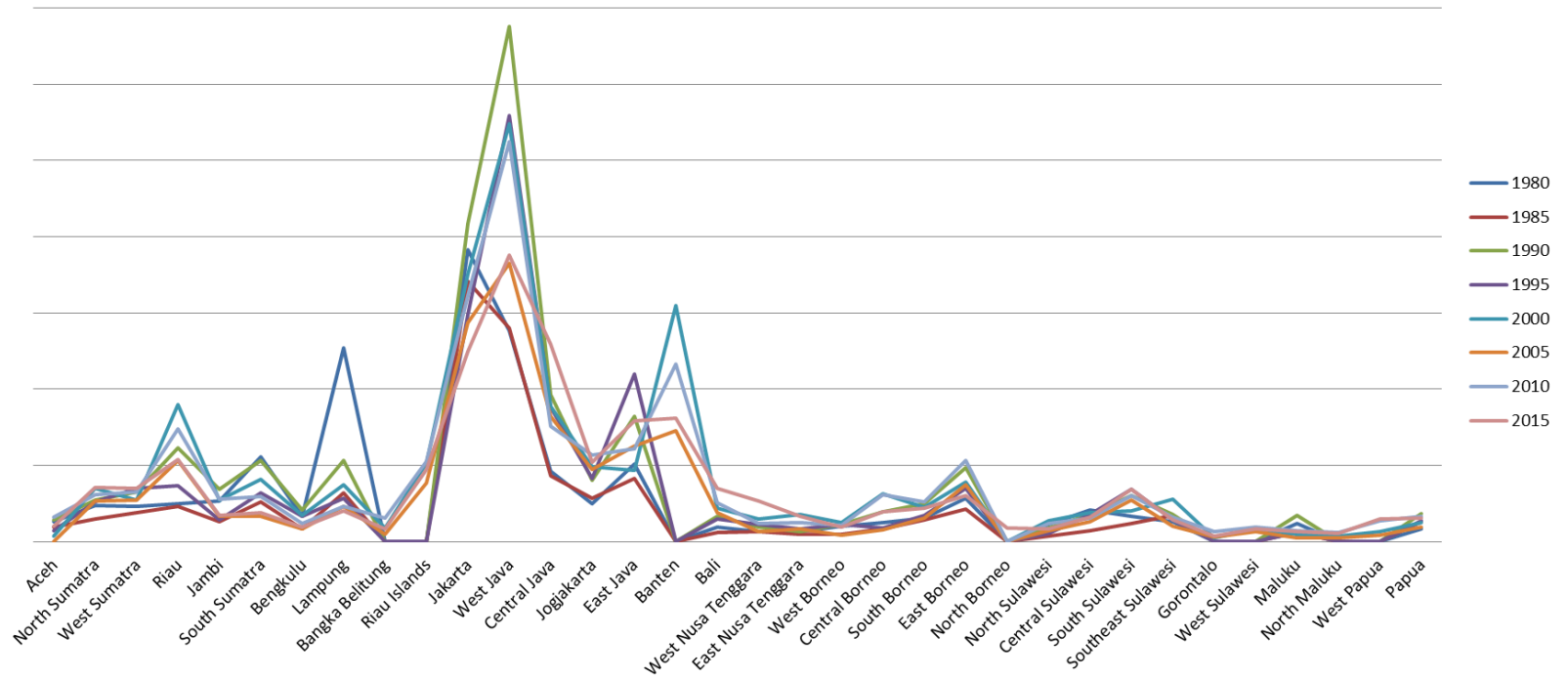

Figure 3. Recent Migration in 1980-2015

Source: BPS, compiled

\subsection{Ethnic Identification in IFLS 5}

The object of observation came from IFLS 5 secondary microdata. In practice, there were constraints related to the completeness of the data in the dataset. For example, there are blank data or data with ambiguity. In the ethnic database, there are two or more ethnic characteristics in an individual respondent are often found. It can happen if his parents come from two or more different ethnicities until the respondent thinks part of both. For this reason, we synchronize the data from the regional languages used and the most controlled by the respondents to determine a stronger tendency for their ethnic history.

For blank data, we synchronize with their parent's ethnicities and also their most spoken regional language. After these procedures, we compare the Population Census data with the IFLS 5 samples, and the outcome is relatively the same and has comparable proportionality. With these results, data can be good accuracy executed according to the real data in the field.

\subsection{Entrepreneurship Comparison}

We identified an entrepreneur by the primary economic activity status. They are Self-Employment, Self-Employment assisted by temporary employees, and SelfEmployment assisted by permanent employees. Furthermore, in simple analysis, we used the cross-tabulation method. As a result, we found that entrepreneurs which SelfEmployment status, and Self-Employment assisted by temporary employee status, had a far higher ratio when compared to SelfEmployment assisted by permanent employee status (Table 2). This trend has not changed for migrant entrepreneurs. Meanwhile, when the entrepreneur is compared with all kinds of employment status, entrepreneurial still far from desirable in-demand. Moreover, more than $50 \%$ of the migrant population works as laborers/employees.

Table 2. Comparison of entrepreneur and non-entrepreneur

\begin{tabular}{|c|c|c|c|c|c|c|c|c|}
\hline & \multicolumn{3}{|c|}{ Entrepreneur } & \multirow[b]{2}{*}{$\%$} & \multicolumn{2}{|c|}{ Non Entrepreneur } & \multirow[b]{2}{*}{$\%$} & \multirow[b]{2}{*}{ Total } \\
\hline & $\begin{array}{c}\text { Self- } \\
\text { Employment }\end{array}$ & $\begin{array}{l}\text { Assisted by } \\
\text { temporary } \\
\text { employee }\end{array}$ & $\begin{array}{c}\text { Aassisted by } \\
\text { permanent } \\
\text { employee }\end{array}$ & & $\begin{array}{l}\text { Laborers/ } \\
\text { Employees }\end{array}$ & Others & & \\
\hline Non Migrant & 5.522 & 6.180 & 610 & & 10.454 & 6.546 & & 29.312 \\
\hline
\end{tabular}




\begin{tabular}{rcccc|cccc}
\hline$\%$ & $\mathbf{1 8 , 8}$ & $\mathbf{2 1 , 1}$ & $\mathbf{2 , 0 1}$ & $\mathbf{4 2 , 0}$ & 35,7 & 22,33 & 58,0 & 100 \\
\hline Migrant & 1.986 & 1.754 & 254 & & 6.836 & 2.558 & 13.388 \\
\hline$\%$ & $\mathbf{1 4 , 8}$ & $\mathbf{1 3 , 1}$ & $\mathbf{1 , 1}$ & $\mathbf{2 9 , 1}$ & 51,0 & 19,11 & 70,2 & 100 \\
\hline
\end{tabular}

Source: IFLS 5, 2015

Table 3 indicates the entrepreneurs with migrant status do not have gender domination. The data shows that the ratio of male migrant entrepreneurs and female migrant entrepreneurs are in the same range, about $29 \%$, only $0.19 \%$ more is for male. The table also shows that the marital status in entrepreneurial decisions is dominated by married, either as migrant entrepreneurs or non-migrant entrepreneurs. Data on nonmigrant entrepreneurs shows that married is above $40 \%$ dominant compared to single. Meanwhile, married migrant entrepreneurs are above $30 \%$ dominant compared to the single migrant entrepreneurs at below 19\%.

Table 3. Comparison of The Entrepreneurs, Migrants and Gender

\begin{tabular}{|c|c|c|}
\hline & Entrepreneurs & Non-Entrepreneurs \\
\hline Non-Migrant & $41,75 \%$ & $58,25 \%$ \\
\hline Female & $40,03 \%$ & $59,97 \%$ \\
\hline Single & $39,98 \%$ & $60,02 \%$ \\
\hline Married & $40,05 \%$ & $59,95 \%$ \\
\hline Male & $43,23 \%$ & $56,77 \%$ \\
\hline Single & $20,99 \%$ & $79,01 \%$ \\
\hline Married & $49,27 \%$ & $50,73 \%$ \\
\hline Migrant & $29,61 \%$ & $70,39 \%$ \\
\hline Female & $29,49 \%$ & $70,51 \%$ \\
\hline Single & $18,60 \%$ & $81,40 \%$ \\
\hline Married & $32,45 \%$ & $67,55 \%$ \\
\hline Male & $29,68 \%$ & $70,32 \%$ \\
\hline Single & $17,68 \%$ & $82,32 \%$ \\
\hline Married & $32,94 \%$ & $67,06 \%$ \\
\hline Total & $37,91 \%$ & $62,09 \%$ \\
\hline
\end{tabular}

Source: IFLS 5, 2015

The summary of the education level and age towards entrepreneurship in Indonesia is shown on Table 4. The data show that selfemployed are predominantly in basic education (primary school, junior high school, and senior high school). Those with higher levels of education are less likely to be an entrepreneur.
It applies to both those who migrate and those who do not. Meanwhile, the age variable shows a parabolic curve pattern. Those who are predominantly entrepreneurial are those who are over 26 years old, then slope with retirement. However, the number of entrepreneurs over retirement is still quite a lot.

Table 4. Comparison of The Entrepreneurship, Education, and Age

\begin{tabular}{|c|c|c|c|c|c|c|c|c|c|c|c|c|c|c|c|}
\hline & \multicolumn{12}{|c|}{ Entrepreneurs } & \multirow{2}{*}{\multicolumn{2}{|c|}{$\begin{array}{c}\begin{array}{c}\text { Non- } \\
\text { Entrepreneurs }\end{array} \\
\text { Total } \\
\end{array}$}} & \multirow{3}{*}{$\begin{array}{c}\text { Total } \\
\text { Number }\end{array}$} \\
\hline & \multicolumn{10}{|c|}{ Age } & \multicolumn{2}{|c|}{ Total } & & & \\
\hline & $15-25$ & $\%$ & $26-35$ & $\%$ & $36-45$ & $\%$ & $46-55$ & $\%$ & $>56$ & $\%$ & Total & $\%$ & Total & $\%$ & \\
\hline Non-Migrants & 634 & $2,23 \%$ & 2356 & $8,28 \%$ & 3170 & $11,14 \%$ & 2800 & 9,84\% & 2672 & $9,39 \%$ & 11632 & $40,87 \%$ & 16830 & $59,13 \%$ & 28462 \\
\hline Boarding school & 4 & $7,14 \%$ & 4 & $7,14 \%$ & 18 & $32,14 \%$ & 2 & $3,57 \%$ & 2 & $3,57 \%$ & 30 & $53,57 \%$ & 26 & $46,43 \%$ & 56 \\
\hline Primary School & 122 & $1,12 \%$ & 698 & $6,40 \%$ & 1178 & $10,80 \%$ & 1638 & $15,02 \%$ & 1894 & $17,37 \%$ & 5530 & $50,71 \%$ & 5376 & $49,29 \%$ & 10906 \\
\hline Junior High School & 164 & $3,09 \%$ & 600 & $11,29 \%$ & 630 & $11,86 \%$ & 464 & $8,73 \%$ & 396 & $7,45 \%$ & 2254 & $42,42 \%$ & 3060 & $57,58 \%$ & 5314 \\
\hline Senior High School & 252 & $2,88 \%$ & 836 & $9,54 \%$ & 1090 & $12,44 \%$ & 570 & $6,51 \%$ & 280 & $3,20 \%$ & 3028 & $34,56 \%$ & 5734 & $65,44 \%$ & 8762 \\
\hline Diploma & 16 & $1,88 \%$ & 84 & $9,88 \%$ & 86 & $10,12 \%$ & 50 & $5,88 \%$ & 50 & $5,88 \%$ & 286 & $33,65 \%$ & 564 & $66,35 \%$ & 850 \\
\hline Bachelor & 76 & $3,18 \%$ & 132 & $5,52 \%$ & 162 & $6,77 \%$ & 76 & $3,18 \%$ & 44 & $1,84 \%$ & 490 & $20,48 \%$ & 1902 & $79,52 \%$ & 2392 \\
\hline Master & 0 & $0,00 \%$ & 2 & $1,14 \%$ & 4 & $2,27 \%$ & 0 & $0,00 \%$ & 6 & $3,41 \%$ & 12 & $6,82 \%$ & 164 & $93,18 \%$ & 176 \\
\hline Doctoral & 0 & $0,00 \%$ & 0 & $0,00 \%$ & 2 & $33,33 \%$ & 0 & $0,00 \%$ & 0 & $0,00 \%$ & 2 & $33,33 \%$ & 4 & $66,67 \%$ & 6 \\
\hline Migrants & 538 & $3,91 \%$ & 1702 & $12,38 \%$ & 1058 & $7,69 \%$ & 434 & $3,16 \%$ & 302 & $2,20 \%$ & 4034 & $29,33 \%$ & 9718 & $70,67 \%$ & 13752 \\
\hline Boarding school & 2 & $7,14 \%$ & 4 & $14,29 \%$ & 0 & $0,00 \%$ & 0 & $0,00 \%$ & 0 & $0,00 \%$ & 6 & $21,43 \%$ & 22 & $78,57 \%$ & 28 \\
\hline Primary School & 84 & $3,05 \%$ & 312 & $11,34 \%$ & 308 & $11,19 \%$ & 180 & $6,54 \%$ & 196 & $7,12 \%$ & 1080 & $39,24 \%$ & 1672 & $60,76 \%$ & 2752 \\
\hline Junior High School & 118 & $4,82 \%$ & 368 & $15,03 \%$ & 216 & $8,82 \%$ & 66 & $2,70 \%$ & 40 & $1,63 \%$ & 808 & $33,01 \%$ & 1640 & $66,99 \%$ & 2448 \\
\hline Senior High School & 208 & $3,94 \%$ & 724 & $13,71 \%$ & 402 & $7,61 \%$ & 134 & $2,54 \%$ & 44 & $0,83 \%$ & 1512 & $28,64 \%$ & 3768 & $71,36 \%$ & 5280 \\
\hline Diploma & 28 & $3,37 \%$ & 102 & $12,29 \%$ & 50 & $6,02 \%$ & 20 & $2,41 \%$ & 10 & $1,20 \%$ & 210 & $25,30 \%$ & 620 & $74,70 \%$ & 830 \\
\hline Bachelor & 98 & $4,36 \%$ & 186 & $8,27 \%$ & 80 & $3,56 \%$ & 34 & $1,51 \%$ & 8 & $0,36 \%$ & 406 & $18,04 \%$ & 1844 & $81,96 \%$ & 2250 \\
\hline Master & 0 & $0,00 \%$ & 6 & $3,90 \%$ & 2 & $1,30 \%$ & 0 & $0,00 \%$ & 2 & $1,30 \%$ & 10 & $6,49 \%$ & 144 & $93,51 \%$ & 154 \\
\hline Doctoral & 0 & $0,00 \%$ & 0 & $0,00 \%$ & 0 & $0,00 \%$ & 0 & $0,00 \%$ & 2 & $20,00 \%$ & 2 & $20,00 \%$ & 8 & $80,00 \%$ & 10 \\
\hline
\end{tabular}




\section{Ethnicity, Migration, and Entrepreneurship in Indonesia}

\subsection{Data Analyzing}

The model of logistic regression also adding individual characteristics and household characteristics. In the test of ethnic tendencies in entrepreneurship, the model uses Javanese ethnicity as the base category.
This ethnicity is used as a reference because its largest population among other ethnicities. We can construe the ethnic groups in Indonesia that tend to be entrepreneurial compared to Javanese are Balinese, Batak, Chinese, and South Sumatra. With an error rate below $5 \%$ (Table 5).

Table 5. Ethnic Estimation Results in Indonesia on Entrepreneurial Decisions

\begin{tabular}{|c|c|c|c|c|c|c|c|c|}
\hline \multirow[b]{2}{*}{ Ethnic } & \multicolumn{2}{|c|}{ No Migration Factor } & \multicolumn{2}{|c|}{ With Migration Factor } & \multicolumn{2}{|c|}{ No Migration Factor } & \multicolumn{2}{|c|}{ With Migration Factor } \\
\hline & Odds Ratio & $P>(z)$ & Odds Ratio & $P>(z)$ & $\begin{array}{c}\text { Marginal } \\
\text { Effect }\end{array}$ & $P>(z)$ & $\begin{array}{l}\text { Marginal } \\
\text { Effect }\end{array}$ & $P>(z)$ \\
\hline Sundanese & 0,962460 & 0,625 & 0,998758 & 0,993 & $-0,009$ & 0,624 & 0,000 & 0,993 \\
\hline Balinese & 1,385960 & $0,044^{* *}$ & 1,164755 & 0,464 & 0,077 & $0,05^{\star \star}$ & 0,031 & 0,471 \\
\hline Batak & 1,460319 & $0,004^{\star \star \star}$ & 1,320055 & $0,093^{*}$ & 0,090 & $0,005^{\star \star *}$ & 0,058 & 0,100 \\
\hline Bugis & 1,334623 & $0,061^{*}$ & 1,231780 & 0,401 & 0,068 & 0,068 & 0,043 & 0,411 \\
\hline Chinese & 3,895962 & $0,025^{\star \star}$ & 0,801242 & 0,767 & 0,327 & $0,014^{\star *}$ & $-0,043$ & 0,758 \\
\hline Madurese & 0,975026 & 0,883 & 1,015270 & 0,961 & $-0,006$ & 0,883 & 0,003 & 0,961 \\
\hline Sasak & 0,994644 & 0,972 & 0,843110 & 0,509 & $-0,001$ & 0,972 & $-0,033$ & 0,498 \\
\hline Minang & 1,003705 & 0,974 & 1,970479 & $0,000^{* * *}$ & 0,001 & 0,974 & 0,146 & $0,000^{* * *}$ \\
\hline Banjar & 1,055703 & 0,659 & 1,415406 & $0,088^{*}$ & 0,012 & 0,661 & 0,073 & $0,097^{*}$ \\
\hline Betawi & 1,123546 & 0,444 & 0,625244 & 0,134 & 0,027 & 0,45 & $-0,087$ & 0,104 \\
\hline $\begin{array}{l}\text { South } \\
\text { Sumatran }\end{array}$ & 1,400064 & $0,013^{\star *}$ & 1,066677 & 0,751 & 0,080 & $0,015^{\star *}$ & 0,013 & 0,753 \\
\hline Migration & 0,719410 & $0,000^{* * *}$ & & & & & & \\
\hline \multicolumn{9}{|c|}{ Source: IFLS 5, compiled } \\
\hline${ }^{*} P<0,1$ & \multicolumn{2}{|c|}{ Number of obs } & \multicolumn{2}{|c|}{$16 \quad$ Prob $>$ chi2 } & \multicolumn{4}{|l|}{0,0000} \\
\hline${ }^{* *} P<0,05$ & \multicolumn{2}{|c|}{ LR chi2(40) } & \multicolumn{2}{|c|}{$8 \quad$ Pseudo R2 } & 0,0908 & & & \\
\hline
\end{tabular}

We also conducted a test by adding migration as an interaction variable to see the trend of the ethnic entrepreneurs overseas. The empirical fact that we found is the Minang has the highest level of significance with an error rate of below $1 \%$, as the ethnics who migrate and become overseas entrepreneurs. These findings complement previous research that concluded the Minangkabau ethnic tradition in migrating aims to be entrepreneurial. Meanwhile, if the margin of error is $10 \%$ raised, the Banjar and the Batak also tend to migrate and then decide to become entrepreneurs. The most interesting is the odds ratio value of the Chinese are different between the individuals who have migration factor and those who have not. We found the Chinese ethnic groups are more likely to be entrepreneurs, but it does not happen when there is a migration intervention. It means that they only tend to be entrepreneurs in the area around where they live.

To measure each independent variable effects on the probability of entrepreneurship, we use the Marginal Effect Method (dy/dx). With a $5 \%$ error level of significance, assuming the other variables are considered constant.
The results are the Chinese ethnic group tends $32 \%$ to prefer entrepreneurship compared to Javanese ethnicity. Meanwhile, the Balinese are more to be entrepreneurial by $7.7 \%$ compared to the Javanese. The Batak ethnic group tends to be $9 \%$ likely to choose entrepreneurship than the Javanese. And, the South Sumatra ethnic group tends to be $8 \%$ more entrepreneurial than the Javanese. When we add the migration interaction variable to the maximum value, the results show that the Minang ethnic group tends to be more entrepreneurial by $14 \%$ compared to Javanese ethnicity.

Furthermore, regarding the effect of individual characteristics (Table 6), the statistical calculations show that age, marital status, muslim, religious, and length of study have significant effects on the model. Regarding the variable length of education, previous literature said that the longer a person takes education, the less likely he is to be an entrepreneur. To prove this, we deliberately entered the quadratic variable to see the peak point of the length of time he studied. This theory based on (Wooldridge, 2013, p. 195) where the $x$ and $x^{2}$ turning points got denoted in the formula: $\beta_{1} /\left(2 \beta_{2}\right), \beta_{1}$ is the coefficient of 
the variable $x$, while $\beta 2$ is the coefficient of $x^{2}$. Wooldridge argued that if the coefficient on $x$ is positive and the coefficient on $x^{2}$ is negative, then the square has a parabolic shape. So that the statistical results obtained 0,3048235 / ( 2 * $0,0177533)=8,585$. It means that the critical point for someone to choose entrepreneurship is when the length of time they have their education is 8,6 years. Below and above this figure, the tendency for someone to choose self-employment will decrease. These findings support Mesch (1997), which shows that education and entrepreneurship are negatively related. The higher education, then the lower opportunities to open a business.

\section{Table 6. Estimation Results of Individual Characteristics Variables on Entrepreneurial Decisions}

\begin{tabular}{lccccc}
\hline Independent Variable & Coefficient & $\begin{array}{c}\text { Standard } \\
\text { Error }\end{array}$ & $\begin{array}{c}\text { Odds } \\
\text { Ratio }\end{array}$ & $\mathbf{P}>(\mathbf{z})$ & $\begin{array}{c}\text { Marginal } \\
\text { Effect }\end{array}$ \\
\hline Age & 0,0387419 & 0,0021811 & 1,039502 & $0,000^{* * *}$ & 0,00901 \\
Male & 0,0038308 & 0,0427886 & 1,003838 & 0,929 & 0,00089 \\
Married & 0,2693345 & 0,0650674 & 1,309093 & $0,000^{* * *}$ & 0,06264 \\
Muslim & 0,2844332 & 0,1111394 & 1,329008 & $0,010^{* *}$ & 0,06616 \\
Religious & 0,0881367 & 0,0431924 & 1,092137 & $0,041^{* *}$ & 0,02050 \\
Education year & 0,3048235 & 0,0432988 & 1,356386 & $0,0000^{* * *}$ & \\
Education year quadratic & $-0,0177533$ & 0,0020424 & 0,982403 & $0,000 * * *$ & \\
Read & 0,1424848 & 0,132565 & 1,153136 & 0,282 & 0,03314 \\
Health & 0,0041328 & 0,0533493 & 1,004141 & 0,938 & 0,00096 \\
\hline
\end{tabular}

Source: IFLS 5, compiled

Constanta $=-4,685012$

${ }^{*} P<0,1 \quad{ }^{* *} P<0,05 \quad{ }^{* * *} P<0,001$

As the results of estimating marginal effects, the tendency of each variable to entrepreneurship is relatively small. The age variable has a significant impact, with a $p$-value of 0,000 and a marginal effect of 0,009 , which means that each increase in age has a probability increase of $0,09 \%$ for selfemployment. Meanwhile, married status has a probability of becoming an entrepreneur by
$6 \%$. The Muslim variable shows a p-value of 0,010 , which means it is statistically significant. So we can conclude that a Muslim is $6 \%$ more likely to be entrepreneurial than a non-Muslim. Regarding religious adherence to the tendency to choose entrepreneurship, the more obedient a person is in religion, the more likely he is to determine entrepreneurship by $2 \%$, with a $p$ value of 0.041 .

Table 7. Estimation Results of Household Characteristics Variables on Entrepreneurial Decisions

\begin{tabular}{|c|c|c|c|c|c|c|}
\hline Independent Variable & Coef. & $\begin{array}{l}\text { Standard } \\
\text { Error }\end{array}$ & $\begin{array}{l}\text { Odds } \\
\text { Ratio }\end{array}$ & \multicolumn{2}{|c|}{$P>(z)$} & $\begin{array}{c}\text { Marginal } \\
\text { Effect }\end{array}$ \\
\hline \multicolumn{7}{|l|}{ Consumption expenditure: } \\
\hline Food Consumption & 0,022258 & 0,00591 & 1,022507 & 0,000 & *** & 0,00518 \\
\hline Non-Food Consumption & 0,000261 & 0,00008 & 1,000261 & 0,001 & *** & 0,00006 \\
\hline Parent's education year & 0,038993 & 0,01821 & 1,039763 & 0,032 & ** & 0,00907 \\
\hline Parent's as entrepreneur & 0,334531 & 0,04818 & 1,397284 & 0,000 & *** & 0,07781 \\
\hline Dominant income in the family & 0,303708 & 0,04905 & 1,354873 & 0,000 & *** & 0,07064 \\
\hline Rural & 0,262367 & 0,04641 & 1,300003 & 0,000 & *** & 0,06102 \\
\hline Household size when kids & $-0,028241$ & 0,03280 & 0,972154 & 0,389 & & $-0,00657$ \\
\hline No Job & $-0,213099$ & 0,08859 & 0,808076 & 0,016 & ** & $-0,04956$ \\
\hline
\end{tabular}

Source: IFLS 5, compiled

Constanta $=-4,276468$

${ }^{* *} P<0,05 \quad{ }^{* * *} P<0,001$

In the household characteristic variable (Table 7), we put variables relevant to the influence of entrepreneurship. We use the level of consumption as the core variable in 


\section{Ethnicity, Migration, and Entrepreneurship in Indonesia}

economic problems expenditure. The result shows that both food and non-food have a significant effect. Likewise, the environmental influence such as; the parent's job, the dominant occupation in the family, and the rural location, have a significant effect with an error rate of below $1 \%$. Meanwhile, the parents' education level and the no job status have a significant impact with an error rate below $5 \%$.

From the table, we can sum up that food consumption expenditure is significant by a margin of $0,5 \%$. Meanwhile, non-food consumption is even smaller. It implies that although the expenditures variables are statistically significant, the percentage likely to influence entrepreneurial tendencies is small. On the other hand, the influence of the environment as measured by the type of work of the parents, and the majority of family members are also entrepreneurs, the results show that a $7 \%$ margin tends to influence an individual's decision to become an entrepreneur as well. However, the level of parental education only affects $0,9 \%$ of the tendency of individuals to become entrepreneurs. For the location factor, the statistical results show that $6 \%$ of those who are self-employed tend to be in rural areas than in urban areas. Meanwhile, the unemployment status shows a significance with a p-value of 0,016 and a margin of $-0,049$, meaning that those who do not work prefer not to become entrepreneurs with a probability of $0,49 \%$.

\section{DISCUSSION}

Because of the largest population, we use the Javanese tribe as the primary comparison to other ethnicities in the model. The statistical result shows that the ethnic tendencies in choosing to become entrepreneurs are very diverse. Among them are the Balinese, Batak, Chinese, and South Sumatran tribes. The four ethnic groups tend to be entrepreneurs where they live. The second finding is that some ethnic groups tend to do entrepreneurship in overseas areas but not in their areas. The Minang has a high significance for entrepreneurial decisions when the influence of migration is further. It is enriching previous research, which states that in matrilineal culture, such as women in Minang, women play a dominant role in the culture. As a result, the Minang men will leave their hometowns (migrating) to another county to speculate after graduating from high school or college (Hastuti, Thoyib, Troena, \& Setiawan, 2015).
Several previous studies concluded the strength of migratory culture in certain ethnic groups in Indonesia. As in the Bugis, Madurese, and others. However, if we look from the tendency of the types of work occupied, entrepreneurship may not be the primary choice overseas. For example, in older the Bugis settlements, most traders were found, while new emigrants, indicating more sailors who mostly moved to ports in Java and to be a farmer, who was interested in a virgin forest on the Jambi coast and Indragiri in Sumatra (Lineton, 1975). In other words, they prefer to be free workers.

There are also notable differences in the influence of individual characteristics on entrepreneurship. The majority of those who are entrepreneurs are married. We can assume that a married person will have a smaller chance of getting a formal job because the job qualification does not accommodate it. By economic purpose, they prioritize official sector work, as employees (both public and private) or laborers at a young age, before being 'forced' into entrepreneurship.

Meanwhile, the length of education has a significant effect. When tested with a turning point, the tendency of entrepreneurship will decrease when education goes higher. It explains the BPS data that people with higher education tend to choose as employees, both public and private, rather than applying knowledge and theoretical insights in creating jobs.

Age has a significant impact, which means that the higher the age, the greater the tendency to entrepreneurship, while health is not statistically significant. However, in terms of gender, entrepreneurs are not dominated by men or women. It is acceptable because basically everyone can have a level of creativity and motivation regardless of gender status.

The previous research discussed how religion influences entrepreneurial decisions. It stated that religious teachings about prohibition, an instance at interest loans, or caste rules, are a factor that holds back entrepreneurial ruling. It also discussed how entrepreneurial decisions inspire by one's faith. As Max Weber (1904) in Dana (2009), comparing Protestants and Catholics in Baden Germany to the tendency to entrepreneurship through the tax rate, the result is that Protestants are more masters of entrepreneurship than Catholics. Meanwhile, in Islamic teachings, religion encourages its followers to do business to avoid other nonhalal income. In this entrepreneurship research, at the $5 \%$ error rate, Islam (Muslim) 
has a more significant effect than non-Muslims. Passingly, if we test a person's level of devotion to their respective religions, it indicates those who show obedience in practicing religion have the probability of more entrepreneurial.

Regarding household characteristics, the tendency of parents' jobs and the most dominant occupation in the same family history, which is as an entrepreneur, has a significant effect on entrepreneurial choice. It is further strengthening the theory that culture influences someone's behavior from generation to generation. Besides, local environmental groups also influence in determining entrepreneurial decisions.

Meanwhile, on consumption expenditure measures, both food or non-food consumption show a significant trend in entrepreneurship, but with a small result. We can interpret that entrepreneurial tendency can be measured from their expenses, even with a low level of significance. From the educational factor, the statistical analysis result shows that the highest tend to choose entrepreneurship is when the length of education is 8.5 years. It means that less and above this period, someone prefers other jobs than to be an entrepreneur. Meanwhile, the length of time of education indicates someone with a junior high school education. Over that time are high school graduates and above. Unfortunately, due to the reasons of risk, business shocks, and financial reasons, people with better education tend to be reluctant to become interested in entrepreneurship (Hadiyati, 2011). It is causing why people prefer to wait for job opportunities in the formal sector, such as private/public employees. The negative impact is, contributing to the number of open unemployment, which has always been a problem in Indonesia from year to year. As the Official Statistics News report released by BPS, the highest open unemployment rate from 2015 to 2020 is dominated by high school/vocational school, diploma, and university graduates.

Entrepreneurship is also still considered an alternative when formal sector jobs have not been yet. It is base on the analysis of respondent's status as not working/no job has a significant effect on entrepreneurship, even with a negative trend. We can assume that those who are looking for an occupation, tend not to choose entrepreneurship as their job choice. Regional influence also appears that those who are entrepreneurs generally living in rural areas. The results also show a significance with the odds ratio in the positive direction. It implies that work as an entrepreneur is more done in rural areas than in urban areas. Generally, jobs in urban areas are prevailed by formal jobs, such as employees or laborers.

\section{CONCLUSIONS AND IMPLICATION OF THE RESEACH}

\subsection{Conclusions}

Refer to the theoretical framework, the cultural aspect has been influencing in shaping social identity and affecting individual choices, including economic activities. Based on the research problem at the beginning of the paper, can be concluded that related to the influence of ethnic culture in entrepreneurial decisions, the results of descriptive and statistical analyzes show that ethnic tendency in entrepreneurship has various variations. Several ethnic groups show that their culture has a potent influence on making entrepreneurial decisions than other ethnic groups. Among them are the Balinese, Batak, Chinese, South Sumatran, and Minang. This trend is not based on population size but based on an analysis of the percentage of choices. It also supports and enriches the previous theory regarding the significant relationship between entrepreneurship and ethnicity.

Furthermore, examining the ethnic migrants' status towards entrepreneurial decisions, we can see from the results of the test analyzing, some ethnic groups are very tight in entrepreneurship in their origins, such as the Balinese, Batak, Chinese, and South Sumatran. Meanwhile, there are ethnic groups that tend to do their business outside their native by migrating, they are the Minang. These results reinforce the theory that cultural teachings have often become the grip or philosophy of each individual from each group in every activity. Javanese people recognize the adage "Mangan ora mangan sing penting kumpul (although we can eat or not as long as we always stay together)" which is very influential in making migratory decisions. It is different from the culture of wandering and entrepreneurship for the Minang ethnicity that is a form of self-existence to become an independent and free person to go anywhere. The principle of "Elok jadi kapalo samuik, daripado ikua gajah (It is better to be the head of an ant than to be the leg of an elephant)" can be interpreted that it is better to be a leader of a small group than to be a subordinate of a large organization, is the economic principle of most Minang people (Handaru, Pagita, \& Parimita, 2015) 


\section{Ethnicity, Migration, and Entrepreneurship in Indonesia}

\begin{abstract}
Regarding the examination of individual and household characteristics on entrepreneurial tendencies, we do multivariate analysis. The result shows that for most ethnicities in the study, both individual and household characteristics do more control and have a dominant effect than the role of ethnic influences. The impact is, it occurs on ethnicity, which the data has a large number of entrepreneurs but in statistical analysis has a marginal result. In this case, it happened to the Bugis, Madurese, and others.
\end{abstract}

\subsection{Implications of the research}

The entrepreneurial tendency concluded can be influenced by references, experiences, lessons, and insights gained from outside. So, as a contribution to reduce open unemployment in Indonesia and strengthen macroeconomic flexibility, the ethnic groups that tend to have an entrepreneurial culture need to be supported and deserve to be appreciated. Meanwhile, to encourage the growth of interest in entrepreneurship in general, several things that might be done are:

1. The Government's focus on entrepreneurship, in general, is on the issue of ease of business capitalization, business licensing, and skills training. These efforts are good at developing a better level of business. However, this is only useful for those who are already running their business. Whereas what is more important is the effort to change the mindset of earning a living from depending on other people, then transform to extracting creativity and innovation from oneself by creating a job by himself. It is necessary to add an understanding and another concept about the meaning of having an income for the new workforce.

2. The authority can carry out an insightbased campaign that can encourage creativity and innovation, especially in ethnic areas with weak entrepreneurial tendencies. Because in the modern era, entrepreneurship opportunities are no longer hampered by classical factors such as accessibility, infrastructure, or high capital constraints. Information technology can be a doorway that could shorten various long roads that may have to be passed by entrepreneurs in the past. Technically, the Government can provide a forum for online creativity, where everyone from all ethnic groups can promote their business marketing.

3. The existing curriculum of lessons and education tends to create skills that prepare a skilled workforce goal, especially in the managerial and manufacturing fields. There are not many lessons that teach or encourage entrepreneurial ideas. So it is not surprising that the higher someone's education level, the less likely he wants to be an entrepreneur. Because at that moment, the skill level of technical expertise and managerial ability will also be rising. The impact is that he will be very ready to be an employee, not to be an entrepreneur. The government should also include an entrepreneurial curriculum in every field of education. So that it will not provides skilled labor only but also generates creative potentials entrepreneurs.

4. In terms of policymaking, this finding implies that the importance of planning and decision-making with further consideration of the various characteristics of different ethnic groups, particularly in terms of job creation. Some policies may not have any impact when they are not well-targeted. Or it will have a good effect when it fits the needs of a particular ethnicity. So, generalizing policies for various ethnic characteristics may produce different results. It will be better if there is more intense coordination between the Central Government and the Regional Government on labor market issues. Due to the fact that The Regional Governments are in the closest position to the characteristics of the local workforce.

\section{REFERENCES}

Auwalin, I. (2019). Ethnic identity and internal migration decision in Indonesia. Journal of Ethnic and Migration Studies, 9451.

Badan Pusat Statistik. (2012). Penduduk Indonesia: Hasil Sensus Penduduk 2010. In Badan Statistik Indonesia. Retrieved from https://www.bps.go.id/

Bandura, A. (1978). Social Learning Theory. Journal of Communication, (October), 12-29.

Basu, A., \& Altinay, E. (2002). The Interaction between Culture and Entrepreneurship in London's Immigrant Businesses. International Small Business Journal, 20(4), 371-393.

Basu, D., \& Werbner, P. (2001). Bootstrap capitalism and the culture industries: $A$ critique of invidious comparisons in the study of ethnic entrepreneurship. Ethnic and Racial Studies, 24(2), 236-262.

Bonacich, E. (1973). A Theory of Middleman. American Sociological Review, 38(5), 583-594. 
Ciputra. (2009). Ciputra Quantum Leap: Entrepreneurship Mengubah Masa Depan Bangsa dan masa Depan Anda. Elex Media Komputindo.

Dana, L. P. (2009). Religion as an explanatory variable for entrepreneurship. World Encyclopedia of Entrepreneurship, 10(2), 87-99.

Decker, R., Haltiwanger, J., Jarmin, R., \& Miranda, J. (2014). The Role of Entrepreneurship in US Job Creation and Economic Dynamism. Journal of Economic Perspectives, 28(3), 3-24.

Dorigo, G., \& Tobler, W. (1983). Push-pull Migration. Annals of the Association of American Geographers, 73(1), 1-11.

Gartner, W. B. (1990). What Are We Talking About When We Talk About Entrepreneurship? Journal of Business Venturing, 5(1), 15-28.

Guiso, L., Sapienza, P., \& Zingales, L. (2006). Does culture affect economic outcomes? Journal of Economic Perspectives, 20(2), 23-48.

Hadiyati, E. (2011). Kreativitas dan Inovasi Berpengaruh Terhadap Kewirausahaan Usaha Kecil. Jurnal Manajemen Dan Kewirausahaan, 13(1), 8-16.

Handaru, A. W., Pagita, M. P., \& Parimita, W. (2015). Karakteristik Entrepreneur Melalui Multiple Diskriminan Analisis (Studi Pada Etnis Tionghoa, Jawa dan Minang di Bekasi Utara). JRMSI - Jurnal Riset Manajemen Sains Indonesia, 6(1), 351.

Hastuti, P. C., Thoyib, A., Troena, E. A., \& Setiawan, M. (2015). The Minang Entrepreneur Characteristic. Procedia Social and Behavioral Sciences, 211(September), 819-826.

Hosmer, D. W., \& Lemeshow, S. (2000). Applied Logistic Regression. In N. A. C. Cressie, N. I. Fisher, I. M. Johnstone, \& J. Kadane (Eds.), A Wiley-Interscience Publication. John Wiley and Sons Ltd.

Hugo, G. (2015). Demography of Race and Ethnicity in Indonesia. In R. Sáenz, D. G. Embrick, \& N. P. Rodríguez (Eds.), The International Handbook of the Demography of Race and Ethnicity Vol. 4.

Humas Kominfo. (2017). Peluang Besar Jadi Pengusaha Di Era Digital. Retrieved June 29, 2020, from https://kominfo.go.id/ content/detail/9503/peluang-besar-jadipengusaha-di-era-digital/0/berita

Indarti, N., Hapsari, N., Lukito-Budi, A. S., \& Virgosita, R. (2020). Quo vadis, ethnic entrepreneurship? A bibliometric analysis of ethnic entrepreneurship in growing markets. Journal of Entrepreneurship in
Emerging Economies.

Latan, H. (2014). Aplikasi Analisis Data Statistik Untuk IImu Sosial Sains dengan STATA. Bandung: Alfabeta.

Levie, J. (2007). Immigration, In-Migration, Ethnicity and Entrepreneurship in the United Kingdom. Small Business Economics, 28, 143-169.

Lineton, J. (1975). Pasompe ' Ugi ': Bugis Migrants and Wanderers. Archipel, 10, 173-201.

Mead, M. (1963). Socialization and Enculturation. Current Anthropology, 4(2), 184-188.

Mesch, G. S. (1997). Occupational Closure and Immigrant Entrepreneurship: Russian Jews in Israel. Journal of SocioEconomics, 26, No. 6, 597-610.

Morrison, A. (2000). Entrepreneurship: What triggers it? International Journal of Entrepreneurial Behaviour \& Research, 6(2), 59-71.

Na'im, A., \& Syaputra, H. (2011). Kewarganegaraan, Suku Bangsa, Agama, dan Bahasa Sehari-hari Penduduk Indonesia. In Sumarwanto \& T. Iriantono (Eds.), Badan Pusat Statistik. Jakarta-Indonesia: Badan Pusat Statistik.

Rossiter, J. R., \& Chan, A. M. (1998). Ethnicity in Business and Consumer Behavior The worldwide increases in migration, tourism, and international trade. Journal of Business Research, 42, 127-134.

Schumpeter, J. A. (1947). The Creative Response in Economic History. The Journal of Economic History, 7(2), 149159.

Strauss, J., Witoelar, F., \& Sikoki, B. (2016). The Fifth Wave of the Indonesia Family Life Survey (IFLS5): Overview and Field Report.

Wayne, L. (1983). The Meaning of Entrepreneurship. American Journal of Small Business, VIII(2), 47-57.

Williams, A. M., Baláz, V., Wallace, C., \& Williams, A. M. (2004). European Urban and Regional Studies.

Wooldridge, J. M. (2013). Introductory Econometrics: A Modern Approach. In J. Sabatino (Ed.), Applied Discrete-Choice Modelling (Fifth Edit). 